\title{
The Impacts of Vocational and Technical Education Programmes on the Empowerment of Rural Dwellers in South-South, Nigeria
}

\author{
Dokubo Isaac Nwojiewho Ph. D \\ Department of Technical Education, Ignatius Ajuru University of Education \\ Rumuolumeni, Port Harcourt \\ Email: dokusii@yahoo.com \\ Dokubo Chidinma Ph.D \\ Department of Educational Foundations, Faculty of Technical and Science Education, \\ Rivers State University of Science and Technology, Nkpolu, Port Harcourt, Rivers State \\ Email: chidinmadokubo@yahoo.com
}

\section{Doi:10.5901/jesr.2014.v4n3p233}

\begin{abstract}
This study investigated the impacts of vocational and technical education programmes as a positive instrument for the empowerment of rural dwellers in South-South, Nigeria. It was predicated on the assumption that vocational and technical education acquisition is closely related to economic empowerment of the rural populace. This programme as well as the curriculum could be designed to take care of the needs of the learners in order to acquire skills necessary for employment, self-reliance and economic development. The acquisition of these vocational skills will greatly help to empower and transform man into a self-reliant person and make him economically viable. This economic empowerment will greatly help to curb or ameliorate the incidence of youth restiveness, kidnapping, militancy and other social vices that are prevalent in South-South, Nigeria. Hence, it is recommended among other things, that government, private organizations and NGOs should adequately support the funding of vocational and technical education programmes, more qualified facilitators and instructors should be trained, more training schools should be built, youths should be motivated to enroll in the programmes by giving them adequate stipends.
\end{abstract}

Keywords: Impacts of vocational eduction programme; empowerment of rural dwellers; self reliance; programme and curriculum design; anti-social vices; unemployment.

\section{Introduction}

The importance of vocational and technical education programmes as a veritable instrument for empowerment of rural dwellers in South-South, Nigeria cannot be over stressed. This because the rate of poverty is very high in this region of Nigeria despite its enormous natural wealth accruing from petroleum products and fertilized agricultural lands (Onyisi,2004). These programmes as well as the curricula could be designed to enable rural population acquire skills and knowledge necessary for economic development, employment, and self-reliance. Consequently, Dokubo (2010) observed that these programmes could be planned to take care of the needs of the teaming unemployed youths and adults aspiring to own small-scale businesses and those wishing to take up employment in the private and public sectors of the economy. Ezeji (2005) posited that there had been a lot of youth restiveness, militancy and other social vices that would have been averted in Nigeria if appropriate technical skills were inculcated into these youths. Therefore, the incidence of youth restiveness, kidnapping, unemployment and other anti-social behaviours that could be associated with idleness and in conjunction with lack of acquisition of technical and vocational skills should have been a thing of the past. In the past, it was observed that several attempts made by governmental and non-governmental agencies towards poverty alleviation programmes and empowerments have thus proved abortive because they could not achieve their set objectives. Dokubo (2005) also observed that, attempts by previous governmental agencies such as, Directorate For Food, Road and Rural Infrastructures (DEFFRI), Operation Feed the Nation (OFN) and National Directorate for Employment (NDE) have cost Nigeria huge sums of material and financial resources to provide various forms of technical and vocational skills for youths in Nigeria.

In 1975 when the Gowon administration was forcefully replaced by the Murtala Mohammed/Obasanjo regime; 
emphasis was placed on acquisition of vocational skills. Obasanjo himself though a Head of State established a large farm. Operation Feed the Nation took off during his administration. Each person was required to acquire vocational skills for agricultural, technical and commercial development. However, government never did much to fund the programme, hence there was no noticeable empowerment on the rural dwellers.

In his own work, Adebayo (1998) stated that vocational education can assist Nigerians to acquire the necessary skills and competence for occupation. He also observed that, from time immemorial, vocational skills and abilities were passed from one generation to the next. He also listed such skills to include: fishing, hunting, weaving, carving etc. He also said that, the outcome of training people vocationally could be rewarding and satisfying, since it could improve the living conditions of the citizens through the vocational education received. Therefore, this means that technical and vocational education is a powerful tool that librates, transforms people into self-reliant humans and empowers them economically.

\section{Areas of Specialization in Vocational and Technical Education}

For any programme to meet its set objective, its design must address the needs of the learners, the needs of institution of learning, that of the society into which the learner belongs and Nigeria at large. Therefore, the areas of specialization will include but not limited to masonry works, Carpentry works, Automobile mechanics, Ceramics productions, Hair dressing/barbing saloon, Leather works/shoe making, Fashion designs/tailoring services, Catering services, Fishery/aqua-culture, Plumbing works, Detergents/soap making, Concrete designs, Automobile driving, Out boat engine mechanics, Tilling works, Painting and decorating work, Computer services, Arts/graphics, etcs

\section{Relevant Theoretical Framework}

Two relevant theories and their implications on vocational and technical education programme as a means of empowering rural dwellers economically and socially are considered. The theories are under the following subheadings:

- McGregor (1960) theory X and Y

- Scientific theory by F. W. Taylor (1949)

\subsection{McGregor (1960) theory $X$ and $Y$}

(i) Theory $X$ states that the average human being has an inherent dislike for work and will avoid it if he can. Because of this human characteristic of dislike for work, most people must be coerced, controlled, directed, and threatened with punishment to get them to put forth adequate effort toward the achievement of organizational objectives.

The average human being prefers to be directed, wishes to avoid responsibility, has little ambition and wants security above all. Therefore, this theory assumed that people are passive and resistant to organizational goals and must be coerced, directed, commanded and controlled if the organization must achieve its objective.

On the other hand, theory $Y$ assumes that:

1. The average human being does not inherently dislike work. Depending upon controllable conditions, work may be a source of satisfaction or a source of punishment.

2. External control and the threat of punishment are not the only means for bringing about effort towards the organizational objectives to which he is committed.

3. Commitment to an objective is a function of the rewards associated with their achievement.

4. The average human being learns, under proper conditions, not only to accept but to seek responsibility.

5. The capacity to exercise a relatively high degree of imagination, ingenuity and creativity in the solution of organizational problems is widely, not narrowly distributed in the population.

6. Under the conditions of modern industrial life, the intellectual potentialities of the average human being are only partially utilized.

Therefore, from the foregoing, people are not by nature passive. Man was created by GOD to have pleasures and satisfaction in all his hard works according to the wise man, King Solomon of the Bible. Also, men are not naturally resistant to organizational goals. If they are, it is as a result of their experiences in the organization. Threats of punishment are not the only means of bringing effort toward organizational objectives. Man will exercise self-direction and self control to achieve objectives to which he is committed. Industrial education programmes should therefore, create such a climate that encourages maximum commitment to the organizational objectives. 
Consequently, it is imperative that learners must be involved in the programme and projects of vocational and education in order for them to carry out the organizational objectives effectively. Nzeneri (2008) posited that when people are involved in need assessment, project identification, planning, execution and utilization of resources, the pride of ownership is achieved. As a result of the above stated reasons, all the participants in the completed projects will see such completed projects as their own and will also protect them from aggressors and destruction. This theory has also shown the need to create good learning environments for vocational education programmes in order to achieve their objectives for the learners and the society at large.

\subsection{Scientific Management Theory by F.W. Taylor (1949)}

The scientific management theory was first introduced by F. W. Taylor, hence he has been known as the father of scientific management theory. Taylor was worried about the low efficiency in industrial establishments, as the industrial revolution of the 19th century had brought along with it socioeconomic changes that led to inefficiency in industry. He began consistent attack on prevailing production management problems. He argued passionately for the use of incentive wage system as a way of getting more output from the workers. Taylor also believed that workers could always exert greater efforts if they are paid some financial incentives based on the number of units of work they are able to produce. He believed that standards could be developed and efficiency improved, and so conducted series of studies on operations and operators. In the first study, Taylor identified and studied the relevant variables in the metal cutting process, thus introducing us to operations oriented analysis. In his research on the movement of iron casting from one place to another, Taylor viewed the operator as an extension of the machine, and suggested that lower cost could be achieved by giving the operator an incentive for increasing his output. He also suggested that lower cost could be achieved by improving the way work was done.

Consequently, Taylor's work had shown the need for monetary incentives to be provided to learners in vocational education programmes as a means of motivating them in the programme. On the other hand, such provisions will greatly empower them economically and also make them have the pride of their vocation. Hence, when people are economically empowered, they could produce more efficiently.

\section{Objectives of Vocational and Technical Education Programmes}

Vocational education, according to Arikpo (2007) is that education which assists Nigerians to acquire the necessary skills and competence for occupation. contributing further on the advantages of vocational Education, Omoruyi and Osunde (2004) remarked that, it is capable of ensuring gainful employment.

opportunities to other members of the society. in other words, Akinelu (1989), also stressed that vocational education programmes can empower adults in the following areas:

1. It releases the persons' power and energy to act,

2. it frees him from all shackles in the way of his authentic self development;

3. It makes him self-reliant and self-confident;

4. It restores his humanity; his self-pride in being the subject, rather than an object, agent rather than a passive recipient of other people's benefactors;

5. It enables him to read the word, reflect on what he had read, and imposed meaning on his environmental reality,

6. It takes him beyond the mechanical or technical mastery of a written word to quality of consciousness, critical reflectiveness, and a changed awareness and perception of his existential situation.

Furthermore, Adebayo (1988) stated that some of the objectives of vocational education are:

a. To provide the technical knowledge and vocational skills necessary for agricultural, industrial, commercial and economic development.

b. To provide trained manpower in applied science, technology and commerce, particularly at such professional level.

c. To give training and impart necessary skills leading to the production of craftsmen, technicians and other skilled personnel who will be enterprising and self reliant.

It is pertinent to note that vocational education is a unique and dynamic human resources development field of study. In effect, Dokubo (2010) showed that various studies have shed more light on the relevance of vocational education programmes on the empowerment of rural adults and poverty reductions in River State, Nigeria among our 
teaming unemployed youths.

\section{Factors Inhibiting Programmes Implementation in South-South, Nigeria}

According to Adebayo (1998), vocational education programmes are being regarded by some people in negative perspectives:

i. Is generally regarded by all, including the majority of the educated few, outside this realm, as education for the never do well or drop-outs.

ii. It is ranked amongst the lowest by Nigerians; the reason is that careers and training in vocational and technical education are lacking in glamour.

The above perceptions by various sectors of our society do not encourage adequate enrolment into this noble profession. Consequently, this low enrolment has given rise to a low out put of qualified industrial education instructors.

Another factor that has become a cog in the wheel of progress these programmes is poor funding. Although efforts of various governments had been an ongoing process, yet it appears that these available vocational education programmes did not empower those who really constituted the targeted population due to inadequate funding of the programmes.

Divergent political interests have also hindered the smooth implementation of most of the skills acquisition programmes in South-South Nigeria. For instance, Dokubo (2007) found out that a skill acquisition centre built in Emohua Local Government Area of Rivers State, Nigeria, is non-functional till date because it was perceived that such a centre may be of benefits to some targeted political opponentss. He further observed that a school -on- wheels programme established in Ibaa community Emohua Local Government Area of Rivers State, South-South, Nigeria, in the 1980's was unable to achieve its set objective of training the rural dwellers vocationally in order to reduce their poverty levels. For instance, the instructors and learners in most of these programmes appeared not to be properly motivated, judging by evidences continued protests, agitations and even open combat by the youths in some communities against poor living conditions arising from, lack of sustainable skills, social amenities and healthy living in these communities of Niger Delta States, of Nigeria.

Looking at the slow pace of these vocational education programmes, there was doubt as to whether the government was actually playing her role for the of the success of the programmes.

It is worth knowing that the knowledge of the extent of impacts of vocational and technical education programmes as a means of empowering rural dwellers, is essential for self-reliance and self-employment, which are measures of sustainable peace and eradication of poverty in the economy.

\section{Empowering Rural Dwellers Via Vocational and Technical Skills Acquisition Programmes}

Vocational education is generally practice-oriented both in principles and practice as could be deduced from the description of such programmes. From the foregoing description of vocational education programmes, it could easily be deduced that every vocational education programme, especially those that focus on vocational skills acquisition, should have the objective of making people more self-reliant and skilful, whether as self-employed or employed by someone else. Kolawole and Adepoju (2007) remarked that vocational education is the ability to use one's skills gainfully and display one's intellectual and economic horizon well enough to be able to tackle very effectively many of the economic problems confronting individuals and the country as a whole. According to Kolawole and Adepoju (2007); the state of affairs where many able-bodied men and women in the society are not gainfully employed in Nigeria, has led to various intervention efforts on the part of the state and federal governments. This state of unemployment has led researchers to question whether the people are actually vocationally empowered. This is because, in a fast changing and unpredictable environment, fostering flexibility relies on solid general education and broad vocational skills which can be updated and completed through vocational education programmes. Vocational education, according to Arikpo (2007) is that education which assists Nigerians to acquire the necessary skills and competence for occupation. In his contribution.

The acquisition of these skills helps the individuals involved to be properly developed and be fitted into the community in they belong.

Another important area in which vocational education programme contributes to the rural transformation is that it provides trained manpower in applied science, technology and commerce, particularly at such professional levels and give training and impact the necessary skills leading to the production of craftsmen/women, technicians and other skilled personnel who will be enterprising and self-reliant. 
Contributing further on the advantages of vocational education, Omoruyi and Osunde (2004) remarked that, it is capable of ensuring gainful employment opportunities to other members of the society. In other words, for most adult learners in vocational education, learning or participation in a learning activity is only supplemental and secondary to their primary role in the society.

Poverty alleviation according to Ossai (2008) is a process, strategy or method through which poverty is alleviated or reduced by sustained increase in the productivity and income of individuals and groups through integrated programmes.

Kolawole and Adepoju (2006) posited that the rate of unemployment in the area (Southern Nigeria) is very high, agreeing with the corroborating remark that poor people are many in Nigeria. The high rate of unemployment has led to a high level of abject poverty, urban pollution and incidence of political thuggery.

Garuba (2004) opined that, education generally plays a critical role in the life of humans, because it presents a solid vehicle for human transformation and empowerment of individuals and the society. Vocational education in particular, is an instrument of empowerment that seeks to provide the adults with the skills required for sound social living.

We have to think of poverty alleviation for sustainable development also as a problem of operational system design; accommodating contexts and conditions, configurations of agents and agencies, and resources covering the materials, motivational, intellectual, and institutional. The most important objective of the programme as perceived kby the trainees and master trainers was to enable the trainees or participants to acquire vocational skills that would make them gainfully self-employed as means of ensuring self reliance and making them more productive and useful citizens.

Since these programmes were intended to empower the rural dwellers for skill acquisitions, it is imperative that effective implementation of vocational and technical education programmes requires that the government should provide: adequate funds, teaching and learning materials, and more qualified vocational education instructors should be trained. It also requires the involvement of learners in programmes/project packages as well as the provision of a conducive learning environment and a positive attitude by oil companies/NGOs for a sustainable vocational education programme is also needed. The provision of monetary stipends to learners in order to support their continuity in the programmes without dropping out is exceptionally essential.

\section{Summary and Conclusion}

The issue of vocational and technical education programmes as a means for economic empowerment and rural transformation in South-South, Nigeria has been exhaustively discussed. Since this paper based its assumption on the premise that vocational and technical education programmes acquisition is closely linked to economic empowerment and poverty alleviation, it is therefore important that the designers of these noble programmes and their curricula should plan them to enable the trainees acquire skills necessary for employment, self-reliance and community development. The acquisition of these vocational skills can liberate the idle minds and transform them into a self-reliant humans and empower them economically Finally, its proper implementation will help to curtail the incidence of unemployment, youth restiveness, militancy and other social vices that are prevalent in South-South Nigeria.

\section{Recommendations}

1. It is recommended among other things that government, private organizations and other stakeholders in the field of education should fund vocational skills acquisition centres adequately.

2. Adequate monetary stipends should be paid to the learners in order to reduce the incidence of drop-outs in the programmes.

3. Furthermore, vocational education should use participatory approach to stimulate active participation of the learners.

4. The learning environment should be provided with essential physical facilities and appropriate social working condition that are free from tension and dangers to the lives of the participants and properties.

5. Oil companies and other NGOs should maintain a positive attitude toward their host communities in areas of skills acquisition because this will enhance the needed transformation and thus create a healthy working relationship with their host communities.

6. More qualified vocational education instructors should be trained and posted to rural areas for effective implementation of vocational education training. 


\section{References}

Adebayo, O. (1998). The future of continuing education programme in Nigeria with particular reference to vocational institutes; $\mathrm{A}$ contribution to the national Workshop on continuing education programme in Nigeria 1 (1) 1-6.

Akinpelu, J. A. (1989). The Problem of relevance in the adult education curriculum; in language and adult education: Essays in University Press. Memory of S.H.O Tomori; pp 21-43; Ibadan; Nigeria.

Arikpo, A. B. (2007). Introduction to philosophy of adult education. Calabar: Wusen Publishers.

Arikpo, A. B. (2007). Principles and practice of extra-mural studies in Nigeria. Calabar; Wusen Publishers.

Dokubo, I. N.(2005).Technology education and youths empowerment -Nigerian Association of Teachers of Technology, 2(3), Port Harcourt.

Dokubo, I.N. (2007). Factors militating against effective teaching of building technology in technical colleges in Rivers State, Nigeria. An unpublished M.Ed thesis, Rivers State university of science and technology Port Harcourt.

Dokubo, I.N. (2010).Vocational education programmes and empowerment of rural adults in Rivers East Senatorial District, Rivers State, Nigeria. An unpublished Ph.D dissertation, university of Calabar, Cross River State.

Ezeji, S.C.O.A. (2005). Empowering the Nigerian youths through effective technology education: Some policy imperatives. Readings in Nigerian Association of Teachers of Technology, Port Harcourt.

Garuba, A. (2004). Adult education and poverty alleviation Programmes in Nigeria: A care for harmonization; pp. Federal College of Technology. Yola: Nigeria.

Kolawole, C.O.O. \& Adepoju, T. A. (2007). Developing functional literate citizens in South Western Nigerian; in Educational Research and Review 2(2) p 019.

Nzeneri, I.S. (2008). Handbook on adult education Principles and practices. Uyo: Akwa Ibom State. Abigab Associates Ltd.

Omoruyi, F.E. O. \& Osunde, A. U. (2004. Evaluating the effectiveness of the national youth employment and vocational skills acquisition programme in Mid-Western Nigeria, in adult education and development; IIZ, DW, No.62 33-42.

Onyisi, J. C. (2004). Eradication of Poverty through Women's participation in adult and non-formal education: A study of Nsukka in Enugu State of Nigeria in Adult Education and Development; IIz DW; No. 62; 25-31.

Ossai, A. C. (2008). Co-operative Societies and poverty alleviation in Calabar South and Calabar Municipality Local Government Area of Cross River State Nigeria. Unpublished masters degree thesis in University of Calabar. Calabar. 